\title{
WHAT VALUES DOES THE SCHOOL PROVIDE FOR STUDENTS AND TEACHERS?
}

\author{
Anežka Hamranová \\ Faculty of Education, Comenius University in Bratislava (Slovakia)
}

\begin{abstract}
School is one of the important factors influencing the values of adolescents. In addition to education, the aim of the school is also to educate students on values that, if adopted, will help them shape their personality, lead a quality life saturated with healthy social relationships, and also the ability to take care of themselves through education and work. The paper presents a confrontation between students' and teachers' views on the values provided by the school. Qualitative research (semi-structured interviews) was carried out on students $(\mathrm{N}=50)$ and teachers $(\mathrm{N}=16)$ of three secondary schools. Most students reported that the school is trying to pass on values related to relationships and social engagement. The most common values presented by the school were friendship, independence, self-worth, propriety, fellowship, independent opinion, knowledge, freedom, justice, persistence, and moral behaviour. Students appreciate teachers being enthusiastic about their subject and their ability to teach correctly didactically, and at the same time appreciate the human side of the teachers' personality. Teachers reported they are most committed to passing on values related to personal (respect and wisdom) and social (tolerance and decency, faith, justice and friendship) qualities. According to the students, the open and friendly atmosphere of the school positively affects the transfer of values to students. The study was supported by grant VEGA 1/0191/19.
\end{abstract}

Keywords: Values, school, students, teachers.

\section{Introduction}

The term 'value' can be understood in three different ways - a quality of things that are related to satisfaction of human needs; a positive evaluation of human relationships; a and general criterium based on which other objects are evaluated (Prunner, 2002). From the pedagogical viewpoint, the most important meanings of value are the following: adolescent value systems; education as a social value; and values and attitudes as a part of content and goals of the educational system (Průcha, 2008).

The school represents the second most important social factor after the family. The school is a space where a young individual forms new relationship with peers, gets to know the workings of social life, integrates into the collective, and creates new values. A schoolchild confronts and assesses the values, goals, and attitudes collected from different sources - parents, extended family, school, peers, other social groups, and media. These value sources influence the formation of the value structure of the child's personality, as well as the value structure of the adolescent, of the group, and of the society in general. The longer and the more intensive the influence, the higher its effect on the value structure. The school is a place where a person spends a significant part of their formative years, and thus it has many opportunities to influence the values of the students. However, since children and adolescents are easily impressionable, it is important to give them sufficient attention and help them with adopting appropriate and socially and subjectively acceptable values.

\section{Research aim and methods}

The main aim of this study was to investigate students' and teachers' perception of values the school presents to its students. Qualitative semi-structured interviews were conducted with students and teachers. The interviews were done individually, recorded with a voice recorder, and subsequently transcribed. The interviews were then analysed using open coding based on an adapted version of the grounded theory. 
Students were asked the following questions: Q1: How would you define the term 'value'?; Q2: What does school mean to you?; Q3: What values do you receive from school?; Q4: How would you describe a good teacher?

Teachers were asked the following questions: Q1: What values does school (teachers) pass on to the students?; Q2: What methods do you use to pass on the values to the students?

\section{Research sample}

Students $(\mathrm{N}=50, \mathrm{~N}=29$ girls, $\mathrm{N}=21$ boys, $\mathrm{AM}=17,4$ years $)$ and teachers $(\mathrm{N}=16, \mathrm{~N}=11$ women, $\mathrm{N}=5$ men, $\mathrm{AM}=45,7$ years) were selected from three secondary schools in Bratislava, Slovakia. All secondary school years were represented (i.e., year 1-4).

\section{Results}

\subsection{Interview with the students}

Q1: All interviewed students had a definition of 'value'. Most of the students used a definition along the lines of "It is something that is important to me." $(P 2, F)$. Some participants defined it as “...the way of how I live my life, or something based on which I make my decisions" (P8, M), “...something based on which I want to behave and make decisions" (P17, F), or “...something I draw from, something I can benefit from, thanks to which I can lead a quality life.” $(P 3, M)$.

Q2: Students perceived school as an institution that provides them with good education and opportunities for personal growth. Many of the participants saw the education part as essential, illustrated by the following answers: "I'd say the education I get from it gives me an entry ticket to university" $(P 12, M)$, "I think school gives us knowledge and teaches us how to confront different opinions" (P3, M), "They teach us to value education." (P50, F). Students also noted the difference in school's attitude towards students in different years: “...in lower years we learned a lot about relationships, with other people and with ourselves, and now it is more focused on education, knowledge, and future." $(P 42, F)$. Most of the students also highlighted school's important role in their personal development: "It helps us to find ourselves." ( $P 3, M)$, “... a preparation for life, teaches us to be more independent” $(P 23, M)$, "School offers me space for confronting my moral opinions, forging relationships, and participating in social activities." $(P 8, F)$. Many participants related this role of school to relationships and social engagement: "Apart from the basic stuff we get during classes, it also helps us with our development in the social area." (P43, F), “...gives us opportunity to create friendships and learn to cooperate"

(P12, M), “Encourages our public engagement." (P4, M). Moreover, students pointed out the development of concrete personality traits or skills: "I can say with certainty that school teaches us independence." (P17, F), “They teach us to think about things in a broader context." (P8, M), "It teaches us critical thinking." (P23, M). Students recognized that school guides them towards values: “...it doesn't just give us knowledge, but it also brings us up as individuals with values.” (P23, $M)$.

Q3: For the most common values passed on by the school, the students mentioned values related to other people, for instance, friendship $(P 26, F)$, fellowship $(P 9, M)$, propriety $(P 45, F)$, moral behaviour $(P 42, F)$, family $(P 8, F)$, but also values related to their own person, such as independence $(P 33, M)$, self-worth $(P 38, F)$, independent opinion $(P 23, M)$, and persistence $(P 17, F)$. Oftentimes, values tied to school's educational role were stated (education $(P 8, M)$, knowledge $(P 16, F)$ ), as well as humanistic values, like freedom $(P 39, F)$ and justice $(P 1, F)$.

Q4: Most of the interviewed students appreciated teachers who are enthusiastic about their subject and are able to teach it in an intelligible and practical manner. On top of the pedagogical quality, students mentioned craving humanistic approach: “A person who knows what they're teaching and how to teach it." (P34, F), “Who is can talk to the student in a way that doesn't give the impression of someone being superior." ( $(P 9, M)$, “They should be able to motivate us, to spark a fire in us, not just fill us like goblets." (P45, F), “Teacher should, first and foremost, want to teach something and show interest in their students." (P26, M), “A good teacher is not just a teacher, but also a human being who doesn't just sit in the classroom, but teaches us who we should be, has an individual approach, is everywhere, and knows how to teach other stuff, no just their subject." (P2, F). Additionally, students appreciated didactic and rhetoric qualities of a good teacher: "They should also have rhetoric and didactic skills because it's important to be able to present a subject to the students in a way that catches their attention." (P33, M). 


\subsection{Interview with the teachers}

Q1: Teachers stated that apart from the value of education (13), they mostly strive to pass on values related to the development of personal and social qualities. The most present values in this area were the following: respect (9), tolerance (9), propriety (8), justice (7), wisdom (6), friendship (6), faith (5), help and protection of the weak (3). Less mentioned values were, for instance, sense of humour (2), interest in public affairs (1), empathy (1), diligence (1), freedom (1), truth (1), optimism (1), spiritual values (1), morality (1), health (1). Materialistic values were not present at all.

Q2: Most teachers stated discussions with students (14) as the most common method of passing on values. Both formal discussions during lessons and informal talks during breaks or after classes belong under this category, and they can be held in a group or with individuals. The next most-cited method was serving as an example (12). Less common methods were related to activities typical for their school or specific subjects: mentoring (2), co-organizing extracurricular activities (1), facilitating volunteering (1), working with primary sources during classes to learn from the history (1), analysing texts or studying literature during foreign language classes (1), solving problem exercises (1), project teaching (1).

\section{Conclusions}

The purpose of this study was to investigate students' and teachers' perception of values provided by the school, via the method of qualitative semi-structured interviews with students and teachers at secondary schools.

According to the students, the school prepares them for life, gives them space to create relationships, to confront their opinions with opinions of others, and to get to know themselves. Additionally, it teaches them many personal qualities, values, and attitudes. Many students perceive the school's role in personal development through the area of interpersonal relationships and social engagement in society. The most commonly cited values taught by the school are linked to other people and social ties, such as friendship, fellowship, propriety, moral behaviour, and family. In addition, the following values that are related to their own person, are also considered important: independence, self-worth, independent opinion, and persistence. The value of education and knowledge is thought of as a natural part of school, but humanistic values like freedom and justice on the part of school and teachers also resonate with students. Positive atmosphere in school influences many processes taking place in school, including the process of passing on and receiving values. Students stated that they usually perceive the atmosphere in school as positive, friendly, and open. They appreciate that they can talk to their teachers openly about many topics and not just those related to education. The interviews uncovered the fact that students do not mind higher demands put on them as long as they are treated respectfully by the teachers.

Teachers state that apart from the value of education, they strive to pass on values related to personal and social qualities, such as tolerance, respect, propriety, justice, wisdom, friendship, faith, help and protection of the weak. Looking back at the student interviews, it appears that many of the values declared by the teachers are also perceived by the students as values they receive from school. Furthermore, the methods used by teachers to pass on these values can be divided into two categories: humanistic approach and professional approach. The first category represents teachers' efforts to serve as a good example for the students, to spend time with them not just during classes but also outside of them, and to be available for a talk. The second category relates to various classic and innovative methods of teaching which push students to think and express their opinions.

Education should be a process of personality cultivation. And as the findings of this study show, the formation of values and value orientation of students undoubtedly represents an important part of education.

\section{References}

Průcha, J. (2008). Pedagogický slovnik. Praha: Portál. Prunner, P. (2002). Výskum hodnot. Plzeň: Eroverlang. 